\title{
The Influence of Interpersonal Communication, Traditional Media, and New Media Sources on Youth's Voting Behavior; A Study of Pakistan General Election 2013 Campaign
}

\author{
Waseem Iqbal $Y^{*}$ and Ghulam Shabir \\ The Islamia University of Bahawalpur, Punjab, Pakistan
}

\begin{abstract}
The study “The Influence of Interpersonal Communication, Traditional Media, and New Media Sources on Youth's Voting Behavior; A Study of Pakistan General Election 2013 Campaign "conducted to determine the influence of interpersonal communication such as ( Parents, Siblings, friend , religious leader ,celebrities teachers and significant other that which source is more significant in shaping voting behavior of Pakistani youth. Along with interpersonal sources research also found which form of media was effectively play part in voting decision of youth in 2013 general election. This study compares both interpersonal as well as media source to find out which is most effective while election campaign and shaping voting decision of youth.
\end{abstract}

For this study survey method was used, in which self-reported questionnaire compressing forty two questions was distributed among 1000 respondents in public sectors universities of Punjab and Islamabad to find out results. SPSS (Statistical Package for Social Sciences) was used for data analysis and statistical testing of the variables. Excel and word document software's were also used for composing, graphics, tables and charts.

The results proved that Parents are most significant predictor of voting behavior of youth, but there level of significance gradually decreasing as compare to prior studies, because of change in source of information of youth. This study exposed that television is still primary source of information but youth's source of political information in transition phase that they are shifting their information sources form traditional media (newspaper, radio and television) to new media such as internet especially youth relay of social media. The study supports the theoretical framework of 'cultivation, agenda setting, dependence theory, uses and gratification and role of interpersonal discussion' that emphasized on the importance of interpersonal discussion and importance of mass media in shaping behaviors attitudes and emotional reactions of youth.

Keywords: Interpersonal communication; Traditional media; New media; Election campaign; Voting behaviour; General election 2013

\section{Introduction}

Elections are integral to democracy and considered as main stage on which edifice of modern democracy can be developed. Elections palpable latent aspects of human behavior and help to identify the factors and considerations that shapes their political dispositions and voting penchant. Through elections by using political will, public decide who will rule the country and how the resources and capitals are allocates. In the context of Pakistan, the political system of Pakistan is still in experimental stages. The Election of 2013 was the $10^{\text {th }}$ election and provided the opportunity for the first democratic transfer of power from one full-term civilian government to another. The Election was held under many Electoral reforms and Amendments. However, Electoral Roll is the main form of political participation in democratic societies. Voting decisions are the most important decisions that the public make which shows that Electoral Roll is the figurative form of political Participation. Elections serves as a forum of nationwide mobilization of people by competing political parties and promotes vertical and horizontal ( round the clock) political and social networking all over the country.

Pakistan is young and pliable nation and it was for the first time in Pakistan during election 2013 that the "right to vote" was viewed as "Social Obligation". In Pakistan there is multiparty system and history shows that people always preferred two main parties "Pakistan People's Party "and "Pakistan Muslim League Nawaz ".But After a huge rally in October 2011 Pakistan Tahreek-e-Insaf was emerged in country as third largest party of Pakistan. Which changed the scenario in political dynamics and youth becomes an electoral target for all parties and media placed a full-fledged coverage as the election activity takes place simultaneously in the different parts of the country.

There are numerous factors which help and influence the voting behavior .Voting is collective activity to show political behavior and help to strengthen the political system. It is a significant instrument providing opportunities to the voters to become active citizens instead of inactive subjects. Therefore, in today's new media environment, political influence on voters in more multifaceted than ever before. Framing Theory (Goffman) suggests that how something is presented to the audience influence the choices people make. Establishment of Cable TV, Internet, Mobile Technologies and Other media development in the recent years in Pakistan putt the common man into the "hotchpotch of Information". Among family, friends, peers, significant others, the media, campaign networks, and the Internet, party, religion, and family are numerous sources of influence attempt to persuade voters during election season. Media has the powerful influence in shaping and re-shaping Public Opinion. As far as back in

*Corresponding author: Waseem Iqbal Y, PhD Scholar, The Islamia University of Bahawalpur, Punjab, Pakistan, Tel: +92 62 9250235; E-mail: waseem.yasir@gmail.com

Received July 11, 2017; Accepted August 14, 2017; Published August 17, 2017

Citation: Waseem Iqbal Y, Shabir G (2017) The Influence of Interpersona Communication, Traditional Media, and New Media Sources on Youth's Voting Behavior; A Study of Pakistan General Election 2013 Campaign. J Mass Communicat Journalism. 7: 343. doi: 10.4172/2165-7912.1000343

Copyright: () 2017 Waseem lqbal Y, et al. This is an open-access article distributed under the terms of the Creative Commons Attribution License, which permits unrestricted use, distribution, and reproduction in any medium, provided the original author and source are credited. 
Citation: Waseem Iqbal Y, Shabir G (2017) The Influence of Interpersonal Communication, Traditional Media, and New Media Sources on Youth's Voting Behavior; A Study of Pakistan General Election 2013 Campaign. J Mass Communicat Journalism. 7: 343. doi: 10.4172/21657912.1000343

Page 2 of 11

1922,The "Walter Lippman" in his book "Public Opinion" Chapter "The World Outside And The Picture In Our Head " argues that the media are the integral and principal connection between events currently happening and the images in the mind of the public. Pakistan's political Culture is still in its changing stages and media penetrated techniques like agenda setting, framing, priming and gate keeping makes the new and change the existing realities. An increasing consumption of digital media, particularly social networking among young people (Dunham \& Silverman, 2008), suggests more traditional sources of political persuasion may not be as influential as they once were extensive past research has attempted to show, with some difficulty, the effectiveness with which each source of political influence is able to persuade voters.

While some predictors of voter decision, such as party affiliation, Party manifesto, Leader Charisma, income, and education, have been established among older, more experienced voters, the opportunity for outside influence is considerably greater among younger, less experienced voters [1]. This model is named as party identification model. Youth can get impressed by the factionalism of their family or Bradri and it shows the influence on the voting behaviors of youth and those who casts their votes for the first time to become a part of electoral process. It also reflects long standing psychological bonding to specific political party and relationship on the level of trust and confidence among family or Bradri that direct youth to vote. Michigan Model of electoral choices explores that party identification is a long term influence and issues, party image and candidate image works as short term influence which leads voters to make a choice. A general consensus among political researchers holds that "parents, schools, peers, religious institutions, and the news media influence the political socialization of children, and roughly in that order of importance" [2]. But even parents, at the front of the list, are no longer considered as powerful an influence as they once were.

Traditionally, research on political socialization has viewed family as the most influential on the political behavior of young voters. Family system theory introduced by Dr. Murry Bowen says family is as an emotional Unit. Parents were seen as the intermediary between child and society and had a powerful influence on lasting values of their children [3,4]. Family considered as the core group in different sociological researches that shapes the interest and preferences that individual has in electoral system of voting. However, even half a century ago, questions were raised as to why parents' and children's political ideologies were not more highly correlated. In Substantive term Studies have explored this relationship [5-8], and although studies suggest that the power has diminished parental political influence still exists.

This study is an additional link in the long chain of political communication studies since the 1950s that have disentangled the factors that influence young voter's decision. Specifically, this study examines the extent to which first-time voters in the 2013 general Election in Pakistan are influenced by communication from various sources around them and what are the sources which affect their parents voting behaviors. In this vein paper examines what psychological factors influenced and determined in voting decisions. Furthermore to explore the effect of street marches, meetings, public rallies, corner meeting, invocation of family tribal and other ties and massive propaganda campaigns. In this highly politicized world of abundant media coverage, celebrity endorsements, and endless Internet commentary, the question raised is whether interpersonal communication with parents, teachers, peers, and religious leaders is still of significant importance to a voter's decision as in the past. In this context, study will explore how far these factors influenced voting decisions of youth and those who casted their votes for the first time under the $10^{\text {th }}$ general Election of Pakistan.

To answer these questions, this research begins with a review of literature on interpersonal and media-related sources of voter influence. A self-report survey of first-time voters will be conduct on post general election 2013 is outlined and results will provide to make possible clear sketch. A final discussion will examines the significance of these results, relates the results to other studies in political communication and persuasion research and provides recommendations for future investigations.

The problem which has given rise to curiosity of researcher is that in the presence of powerful media exposure, interpersonal communication still very influencing on young adults voting behavior. This study has designed to identify the factor which influences voting behavior. The problem, which we investigate, is that whether interpersonal communication and media exposure affect voting behavior of young adults who cast their vote first time and which factor affects more.

The major object of this study is to identify and examine the effectiveness interpersonal communication and media exposure in shaping voting behavior of young adults, to explore which factor of interpersonal communication (parents, family or peers) is more influencing on young adults voting behaviour and to explore which media source (newspaper, television, radio or internet) is more important in shaping voting behaviour of young adults.

The general election 2013 saw unprecedented voter participation. In the primaries alone, voter turnout increased more than 20 percent over the 2005 primaries. There was 86.19 million residents were registered voter in electoral lists of Pakistan. A significant improvement was observed in turnout $55.02 \%$, which was the highest since 1970 and 1977. The Pakistan Muslim League-Nawaz (PMLN) got one third majority to make a powerful government. They are four times more seats than the seats obtained by Pakistan People Party (PPP). The Pakistan People party was $2^{\text {nd }}$ largest party according to seats, and third largest according to the votes she obtained. On the other hand Pakistan Tharike Insaf (PTI) appeared as $2^{\text {nd }}$ largest party according to the votes and third largest party to the obtained seats. Imran Khan seems to be the only politician ahead of the political learning curve, skilfully using social media to attract a younger demographic of voters. On the other hand, the major parties haven't focused on youth issues with any degree of consistency or seriousness. What do we know about these young voters' behaviours? Prior research says that as compare to experience voters the young voters are more influenced from the election campaign messages [9]. It is assumed that younger voter have less party identification then that of experienced voters [10]. In addition, younger voters chose a candidate much later and wait until closer to the election [11].

A large number of younger people cast their vote for the first or second time in the instant election and were inexperienced voter. According to details of voters released by the Election Commission of Pakistan, out of entire 84.3 million voters, $47 \%$ votes ( 40 million voters) were cast by the young adults aged between 18 and 35, of which 16.2 million are between 18 and 25 years, including 1.58 million voters who turned 18 between January $1^{\text {st }}$ and May $31^{\text {st }}$ in the year 2013. This data beg the question: what role was played by these young voter and which media form and shape kept more influence in making voting decision? Whether these 40 million strong youth has truly understood 
and internalized the importance of democracy and the power and value power of their vote. Second question is that, so many researchers conducted on both young and old voters but researchers find little research on what are the sources which effects voting behaviour and sought out difference on the base of medium and their intensity of effect on the base of generation gap. Here researcher tried to find out what campaign sources mostly effect young as compare to their parents and to find out why their parents remain loyal to same party for years.

This study helps to develop understanding how and why casting vote is a significant issue in a democracy and, so unsurprisingly an abundance of research has been conducted on the various sources of information and predictors of an individual's vote choice. While nowhere near exhaustive, the discussion of the research that follows outlines generally understood comparative factors of influence on young adults voting behavior, they have less experience to poll or first time poll vote. This study indicates which factor influence the interpersonal relationships, such as peers and family members, are others and to analyze the role of the media exposure such as traditional media, and new media in recent elections.

This study is important for shaping voting behavior in general election of Pakistan following reasons. First, the results are of beneficial to the candidates and their political parties. In practical terms, the results will provide information to candidates and political parties about the most effective type of media advertisement and promotion of promotion of election campaign to influence the voters and to give exposure of internet and social media to the candidates and political parties foe effective election campaign.

This study results provide evidence that interpersonal discussion of political issues is critical to voters' decision processes. As long suspected by communication scholars, the media may effect on knowledge levels and actions taken by voters, similarly as interpersonal communication and discussion between citizens dose. This discussion obviously adds to the level of knowledge about political parties, candidates' stand on issues, and their background and increases the likelihood of voting. Media, political parties and candidates are the beneficiaries of this research. As research deals with the better understanding of public voting habits, how information is viewed, collected and shared with others, and how that information is used to gain knowledge and make decisions has far-reaching implications to political campaigns and other political endeavors, and also develop understanding how voter demographics play role in their political socialization and casting vote. These findings could influence the use of media in other national, state and local campaigns and policy promotions. In last but not least this research also educate voter about role of media and interpersonal communication on their political process of casting vote.

To study the effects of media on voting behavior, one must turn to the political socialization literature. Political socialization research focuses on the process through which people come to develop their political value and behaviors.

Political socialization plays a vital role in developing political beliefs which has been underestimated by previous research [8]. "Political socialization can be defined as the study of the growing processes in which youngsters and teenagers attain political intellect, behavior and attitudes". It is the process in which young adults learned their values, attitudes and other behaviors. Political socialization further refined as the process through which one generation transmits political norms and behaviors to next generation. According to Jaros study of political socialization is the education of political orientated and is concerned with explaining how people acquire their political orientation and behaviors. The major concern of political socialization focused on who dose the socialization and process through which it is accomplished.

Numerous research studies regarding political socialization concluded that political structure or political societies and its socialization agents were comparatively functional in communicating define political information, norm ethic attitude and behaviours which individuals digested without much peculiar clarification [7,12-14] However all these researches unsuccessful to examine the element that youngsters go through a stage where they often question what parents, sibling other interpersonal sources and school teach. Youngsters able to shape their political identity, formation political view point, once they started following news and sharing their views in conversations. Kiousis et al. [15] refuted the model of political socialization. Jennings and Niemi also concluded that correlation between parent adolescent in terms of political opinion was low, they concluded that usually political views of parents did not convey to their teenagers.

In the process of identity formation youngster intensively relay on peers. McDevitt and Kiousis 2007, claimed that political activism is a process in which family, peers and school play a role as socialization agents advertising trouble voting, while peers group conversation progressive political activism. Such results show that political socialization is not just the process of advance measured by adults. Once we consider the freedom seeking of youth ended through peer discussions, self-search with unique citizenship and engagement can be popularized.

According to Jennings and Niemi in empirical study that parents are more influential than teachers or peers. In that study political association was compared between parents and child, teacher and child and peer with child. After reviewing the studies to date, Beck concluded that of these agents, parental learning has more influential, "there are no other agents which can compete with the parents in their impact on wide variety of political orientation" (p.139). Hyman [16] in their first summary of political socialization research conclude that parents are primary agents of political socialization but there influence is minimal.

Jennings and Niemi's [7] study reflects parents as agents of political socialization but with weak association and to the extent of party affiliation. In fact, the only consistent political socialization measure that linked parental influence to children's political orientation, albeit weakly was party identification [7,16]. Parents and child partisan agreement effects were strengthened when parent discussed politics with their children [7]. Beak conducted a research with results showed that the picture of parental influence on political socialization is one of extreme potential, but very little follow through, nothing that the transfer of political value may be a parental priority. In a later study among college-aged students, partisanship remained strongly tied to parental influence. Mirroring Connell's contention; agreement on overall political values was noted as merely moderate [17]. Adding to the debate, Glass and Bengtson [18] suggested that reciprocal influence was in play between parents and children. Parents influence the development of political beliefs, but adult children influence parental attitudes later in life. McDevitt and Chaffee [19] take a similar approach; suggesting that even in adolescence, children may influence parental political beliefs to some extent. Though the explanations differ, research has consistently demonstrated the influence of the family on party affiliation and to a lesser extent overall political opinions.

Several interpersonal influences on political beliefs have been identified by scholars, chief among them are peers and family members. 
Citation: Waseem Iqbal Y, Shabir G (2017) The Influence of Interpersonal Communication, Traditional Media, and New Media Sources on Youth's Voting Behavior; A Study of Pakistan General Election 2013 Campaign. J Mass Communicat Journalism. 7: 343. doi: 10.4172/21657912.1000343

Family members have been identified as the strongest influence on political socialization. In many situations, peers have a major influence on their friends, particularly among groups of young adults. Teenagers frequently attempt to "fit in" and experience peer pressure to conform. Peers heavily influence decisions regarding social activities. Friends do not, however, play a major role in forming political beliefs in the middle school or high school years $[8,20]$ called peer influence "limited at best" (p. 342). Only when the attitude is of great importance to the group, or when the group is politically involved, is peer influence a socializing factor. Research has concluded that peer influence is also greater for students actively engaged in civic education because of increased exposure to the political ideas of others [21,22]. Overall however, peers do not heavily influence political orientations. Friends may play a more considerable role in influencing the political beliefs among college students, but further examination of the degree of influence is required.

Recent research suggests that family may not be the predominant influence it was once considered, especially not in the traditional topdown pattern. Sapiro [23] calls for further research into explore new generation political socialization for casting vote. She highlights the necessity of "discovering the procedures, phases, and systems in the development of political orientations and performance" in an everchanging world" (p. 18). Evidence is mounting that increased access to the Internet and other media has an impact on a young adults' political identity formation. Perhaps the family has taken a back seat in the information age. In order to explore this further, it is necessary to examine research on the media and Internet as socializing agents.

Elections as the source of graphing the common choice by electorates and the impact of media in determining the voters desires in candidate choice as well as in other political behaviours and attitudes is indivisible and open \& shut. The impact of media in shaping voting preferences was analysed in early 1940s and 1950s and the fundamental studies suggested negligible role of media in shaping voter choice has recommended in his book "Culture, Society and the Media "that the part of media sustain to raise with the circulation growth and media started winning public belief over political vision, thus initiates to shape the public choices.

Willis [24] indicate in his recent work by "The Media Effect: How the News Influence Politics and Government" admitted the 1968 presidential election studies in US and found a interrelationship amongst the issues highlighted and disseminated by media and the voters care for said issues. George A. Comstock and Erica Scherer's shared views in their published work on "The Psychology of Media and Politics" that the circulation of mass media effected the stability of factors of voting behaviour and attitude of people and by 1970s media developed the reader of voters priority, macleod finds in his study that media encourage discussion between public and encourage them to select party loyalty affiliation, and to cast vote. In the British general election the role of media found complicated. Future US election turnout studies were conducted to investigate the drop in voters turn out and that hard news had little impact over voters and marked that those who avoid voting were politically awarded. In 1996 Joseph Klanner claimed in his book "Effect of Mass Communication "that media effect voting more than the network of other aspects, it effects straight in many situations and also it effect indirectly [25]. Additional impact of media was established in 1984 Noelle Neumann in his work "Spiral of Silence " in which she claimed that Christian democratic party misplaced election due to the biased reporting of TV anchor who aired unfavourable thoughts about party [26]. The belief about media's role constantly to emphasize by later publicized works by William
Lockleys Miller in his "Media and Voters" book and focused of the political attitudes and voting tactics to judge voter perceptions and concepts [27]. In 1992 Teixeira also recommended that many media causes effect the voting behaviour of people and increase the turn out. Furthermore Everett Rogers in 1994 in his study over the "Inter Media Processes and Powerful Effects of Media" found that media acting a pivotal role in setting agenda, ranking the public to which news is significant and henceforth impact voting behaviour choices [28].

Roumeen Islam indicate in her work "Information and public choice that from media markets to policy construction" found that media gratified effect voting as the policy makers have to accommodate the well informed voters [29].

Jennings Bryant and Dolf Zillmann publicized a book in which Macleod and Konicki's work was published. They aimed in their study that the impact of media on voting attitude and behaviour with interpersonal communications. As revealed in "Media and society: Critical Viewpoints" by Graeme Burton that it's wrong to say that media has no influence on voting behavior but it is yet to discover how and why it effect the voting [30].

Muhammad Nawaz Mahsud and Noman Yaser in their study "Effects of Exposure to electronic media political content on voters voting behaviour" gather data from different areas of Lahore and they found it out that most voters in urban areas who are literate were directly influenced by media and take media as source of guidance to shape their voting patterns. The conclusion showed the research hypothesis "the exposure of political information directly propositional to the more the voter spends time on one type of mass media political content" [31]. Media is one of the factor of voting attitude and behaviour but in case of less interaction with media other factors have more impact like particular affiliations, party loyalty and more important is "Baradari" [32]. This was also established by Fozia Nadeem and Dr. Mughees Ahmed in their research work "social system influences political system: A relative study" (Ahmed and Nadeem).

Research indicates that an individual's pattern of media use has an influence on the political participation. On the one hand, the media can increase voter participation through the interacting relationship between political interest, voting and learning from the media. A study by McLeod and McDonald, as written in Sotirovic and McLeod in 2001, realized that use of media is responsible in increase of political understanding, capacity and even voter gathering. The media offers the voter with efficient info to make reasonable voting conclusions and so promote political interest [33]. Even horse race media can have a positive effect while stimulating greater political involvement and reflection through an increasing perception of the political actors. This is especially related to an increase in donating money to parties [34].

For the purpose of this study, traditional media outlets included radio, television, and newspapers. Studies as early as the 1920s began testing the influence of media on voters. The earliest theories held that the media had a powerful ability to change voters' attitudes and behavior [35]. This was followed by an oppositional wave of theories suggesting that the media had little to no influence on voter decision. Finally, in recent years a balance was accepted that the media must do more than "reinforce the status quo." Media are seen to be the primary source of information and also agenda setter that determine what in an election is important enough to spend time discussing [36,37]. Thus, traditional media still have a very important role in influencing voters during election season.

The Internet as a new medium with a great potential for facilitating 
Citation: Waseem Iqbal Y, Shabir G (2017) The Influence of Interpersonal Communication, Traditional Media, and New Media Sources on Youth's Voting Behavior; A Study of Pakistan General Election 2013 Campaign. J Mass Communicat Journalism. 7: 343. doi: 10.4172/21657912.1000343

higher levels of political participation emerged in the last decades, namely the World Wide Web (www). The appearance of this new communication technology has led to an alteration in the way many people fold news and take part in politics. The Internet conglomerates of the audio visual element of traditional media such as television with the fast interactive actions of media such as telephones. It provides the user with a new kind of communication flexibility by its features, enables the individual to choose the preferred information anywhere and anytime regardless of geographical distance. The society is shifting from traditional news sources to a greater reliance on new media, such as Internet [33].

In general, it is suggested that the civic and political engagement of the youth is steadily decreasing, which is facilitated by extensive media use [38]. However, some studies claim that this decline is more related to negative or critical attitudes and ideas young people have about politics [39]. Obviously, the Internet offers a vast amount of opportunities to engage oneself politically. This is particularly the case for the youth who is often politically engaged at local levels and in less traditional forms of political participation [40]. Young people can take part in civic as well as political discussions and inform themselves about current political actions and backgrounds [41]. Especially the domains of building social networks seem to be responsible for increase in political participation. Most online activities are positively related to political participation, such as attending online communication forums and service use. De Vreese [40] pointed out the creation of a "digital citizenship", whereby online communication and online service use among young people correlates with online political participation. There were some concerns that the higher amount of spending time online may lead to abandon the social environment, whereas others stress the potential of electronic media to strengthen social relationships. In a nut shell, social networks seem to performance a significant role in the development underlying political participation of special interest are interpersonal discussions in which disagreement occurs. Researchers claim that such discussions provoke the greatest cognitive activity when individuals are confronted with differing opinions. These confrontations offer individuals the opportunity to learn about each other and to reason about their different ways of thinking. The contact to different philosophies through interpersonal dialogs can not only increase the understanding of their own points on the matter, but also differences to other point of views [42]. When young people leave their familiar environment for going to the college, a lot of new experiences are made with regard to meeting other students coming from different backgrounds. Therefore, a lot of different personalities are converging, which eventually results eventually in diverse discussions.

Through interpersonal communication, the process of reflective integration can be stimulated. Reflective integration is the propensity to think about certain topics, recall them later and seek more information about them. Through the process of reflective integration, the process of information-seeking could be stimulated, and thereby enhancing the political activity of an individual. Especially when different kinds of news, views knowledge and information from different sources are used, the individual is provided with a more contextualized kind of the political domain, which might lead to higher degrees of political participation. Further, the tendency to gain a better insight into news stories might be due to the scepticism about news accuracy and correctness [43]. Especially among college students, the reflective integration of news plays an important role because of their general sceptic perception of the political domain as mentioned above [40]. Research shows that reflective assimilation not only improve the effect of public affairs in newspaper use on political participation but also seems to attenuate the bad effect of television entertainment use on political input. Further, the effects of media seem to be modulated by the processing strategies people use. When a medium encourages people to put some effort into discover precise information, it can provide them with a lot of politically useful content [43]. This could be especially interesting in the case of the Internet due to its self-selecting character.

The Internet is gaining ground against television as the most relied upon source of news during the election. In 2006, 25\% of Americans reported the Internet was their primary source of news, up from $18 \%$ in 2004 and only 7\% in 2002 [44]. During the 2008 election season, $46 \%$ of Americans indicated they used the Internet, email, or cell phone text messaging to get or share campaign news [45]. The Internet offers information to young adults via candidate websites, political blogs, and social networking sites. During 2008 election thirty five percent of Americans stated that they watch political videos on internet and ten percent say they used their Facebook or MySpace sites for information seeking. One of the reasons the Internet is becoming more popular is that more and more it is viewed as a trustworthy source of information, sometimes even more trustworthy than traditional news media. A study of 197 university students in Florence, Italy, found a significant positive correlation between distrust of traditional media and the search for alternative information online [46]. In addition, the interactive nature of the Internet allows for the free flow of political discourse with friends, family, and strangers alike.

The Internet helps young voters establish and formulate a political identity. One study found that young activists in the UK recognized that internet as a more useful means of communication than traditional news media, not only for getting political knowledge and information, but also for creating their personal political identity [47]. A large forum for online political participation is done through social networking sites, which have become significantly more prevalent in the four years since the last presidential race. Because young adults are the primary demographic using Web 2.0 sites, the potential for political influence is greater among voters of this age group.

Also referred to as Web 2.0, online social networking sites have become a trusted forum for political discussion among friends, strangers, and campaigns. With so much participation by candidates and other political organizations, these sites have played an increasingly important role in elections since 2004, when sites like MySpace, Facebook, and YouTube were first becoming popular. Web 2.0 involvement was felt early in the 2008 election cycle when several Democratic nominees, including Barack Obama, Joe Biden, Hillary Clinton and John Edwards, announced their decision to run for president in videos online. Mid-election reports indicate $10 \%$ of Americans used their Facebook or MySpace pages to discuss politics or get information about the election.

The function of social networking sites in elections is has reached the status of being a campaign necessity. Generally speaking, social networking sites in the 2006 election were credited with mobilizing people to become involved politically who might not otherwise have [48]. In the 2008 election, social networking was credited with giving Obama's campaign an edge among younger voters [45]. According to Dunham and Silverman (2008), Obama boasted 2.8 million Facebook supporters compared to McCain's 620,000. On YouTube, 1,821 videos were about Obama versus 330 about McCain. Obama had 870,000 MySpace friends compared to McCain's 225,000, and there were 9 million more searches for Obama on Google than for McCain. In the end, Obama received 66 percent of votes of people under age 30 
Citation: Waseem Iqbal Y, Shabir G (2017) The Influence of Interpersonal Communication, Traditional Media, and New Media Sources on Youth's Voting Behavior; A Study of Pakistan General Election 2013 Campaign. J Mass Communicat Journalism. 7: 343. doi: 10.4172/21657912.1000343

Page 6 of 11

However, because of the relatively recent surge in popularity of Web 2.0 sites, there has been little opportunity to test the prevalence of communication through online social networks as a source of influence on voters. Considering young adults are the primary users of Web 2.0 technology, the level of influence of these sites compared to other media will be useful to determine.

\section{Hypotheses}

All the literature research studies; helped in building certain hypothesis and research questions.

H1: Youth's party affiliation will be positively associated to parents' party affiliation.

$\mathrm{H} 2$ : Parents are a more significant as compare to peer/other in interpersonal source.

H3: Media exposure (newspaper, television, radio and internet) are more positively associated than interpersonal communication in voting behaviour of youth.

\section{Methodology}

In this research, the researcher used field survey technique. Keeping in view the importance of phenomena under investigation, it was appropriate to approach the target sample of population through well designed research questionnaire to inquire Influence of Interpersonal Communication and Media Exposure on Voting Behaviour of Youth. Survey used to explore the consumption patterns of youth for information on political issues. Collection of information through systematic manner in which all units of interest population well defined and assembles such useful concise form. . Researcher used cluster sampling technique to collect a sample of 1000 students of different public sector general categories from Punjab provinces and Islamabad of Pakistan, 500 from each gender. In we go through Pakistan political history, we found there are numerous brake down or patches big martial law form Armed forces. So political socialization of common youth disturbed badly. On the other hand ordinary significant number of Pakistani youth illiterate or low education, and they know very little above voting power and true sprite of democracy.

\section{Data interpretation}

Descriptive survey was used for data collection, and a questionnaire used as tool of data collection. There were 1000 respondents were selected for this research. Out of whole sample size respondents 52.8 percent were male respondents and 47.2 were female participants. Out of them 50.90 percent respondents were between 18-21 years of age, 24.50 percent were $22-24$ and 15.10 percent were in $25-27$ years age and 9.40 percent were between $28-30$ years age group. Statistic results showed that 43.40 percent respondents were undergraduate 39.60 percent were graduate 15 percent were post graduate and 1.9 percent respondents were belong to other categories. Family income varied among the participants; 9.40 percent respondents 10000-
20000, 13.70 percent 21000-30000, 16.2 percent 31000-40000, 22.2 percent 41000-50000 and 38.5 percent earn more than 50000 Pakistan rupee. The sample also represented a range of political ideologies, with 41.50 percent reporting liberal or slightly liberal beliefs, 32.2 percent moderate, and 26.30 percent reporting conservative or slightly conservative beliefs. Similarly, participants consisted of 41.5 percent Pakistan Thareek-e-Insaf, 34 percent Pakistan Muslim League Nawaz, 3.9 percent Pakistan People Party, 13.20 percent associated with other parties and 7.40 percent reported no preferences. Nearly 50 percent respondents reported that their primary source of political news is television, while internet/social media stood second with 24.50 percent as primary source of respondents, newspaper 11.30 percent, family member 7.50 percent, radio 5.70 percent and 1.90 respondents reported other media for political news. In response to the question, was that your first time voting in a general election 2013? 68 percent reported yes while 32 percent said it was not there first time voting experience. 43.30 percent respondents reported they frequently talk about politic with their family, while 39.60 percent reported that they are more likely to talk about politic with friends, 16.90 responses shows respondents are more likely to discuss politics with their teachers religious leaders or significant others. Statistic shows an interesting result that television, internet and social media network have equal weightage for likelihood of interpersonal political discussion.

Before analyzing Youth voters' index of voting choice is influenced by social media as compare to other media sources e.g., newspaper, television and radio etc. Researcher find-out intensity of different media sources usages of youth for political information seeking. According to statistic television is prime source of information seeking of youth. Social media, newspaper and internet news are near to each other in the accession of information, while blogs and radio are least important for the political information sources.

\section{Hypothesis 1: Youth's party affiliation will be positively associated to parents' party affiliation}

Stepwise-multiple regression was used to determine the association between youth political party's affiliation and their parent's political party affiliation. Mother and father party affiliation are independents variable while youth party affiliation is dependent variable. Multicollinearity was checked by tolerance value of each independent variable. Tolerance value of each variable exceeded from 0.1 . The highest tolerance value is .993 and lowest value is 0.717 . The result indicates that "Mother" and "Father" were significant associated predictor of youth party affiliation, $\mathrm{R}^{2=} .236, \mathrm{R}_{\text {adj }}^{2} .234, \mathrm{~F}(1,710)=138.42$, $\mathrm{p}=.000$. This model accounts for $23.6 \%$ of the variance for youth party affiliation associated with parent's party affiliation (Table 1 ).

Mother and father reflect positive association among their party affiliation and their children, in final model these two included "mother" $\beta=.206, \mathrm{t}(901)=5783, p=.000$ and "control" $\beta=.337, \mathrm{t}$ (901) $=9437, \mathrm{p}=.000$ (Table 2).

Results indicate that there is signification relation or positive

\begin{tabular}{|c|c|c|c|c|c|}
\hline \multicolumn{2}{|c|}{ Model Summary } & \multicolumn{2}{|c|}{ ANOVA } \\
\hline Model & $\mathbf{R}$ & R Square & Adjusted R Square & $\begin{array}{c}\text { Std.Error of the } \\
\text { Estimate }\end{array}$ \\
\hline 1 & $.400^{\mathrm{a}}$ & .160 & .159 & 1.212 & 171.037 \\
\hline 2 & $.485^{\mathrm{b}}$ & .236 & .234 & 1.157 & $.000^{\mathrm{a}}$ \\
\hline
\end{tabular}

aPredictors: (constant), what political party does your mother prefer?

'Predictors: (constant), what political party does your mother prefer?, what political party your father prefer, please indicate the name? Table 1: Summary regression coefficient for youth party affiliation associated with their parent's party affiliation. 
Citation: Waseem Iqbal Y, Shabir G (2017) The Influence of Interpersonal Communication, Traditional Media, and New Media Sources on Youth's Voting Behavior; A Study of Pakistan General Election 2013 Campaign. J Mass Communicat Journalism. 7: 343. doi: 10.4172/21657912.1000343

Page 7 of 11

\begin{tabular}{|c|c|c|c|c|c|c|}
\hline \multicolumn{2}{|r|}{ Model } & \multicolumn{2}{|c|}{ Unstandardized Coefficients } & \multirow{2}{*}{$\begin{array}{c}\text { Standardized } \\
\text { Coefficients } \\
\text { Beta }\end{array}$} & \multirow[t]{2}{*}{$\mathbf{t}$} & \multirow[t]{2}{*}{ Sig. } \\
\hline & & $\mathrm{B}$ & Std. Error & & & \\
\hline \multirow[t]{2}{*}{1} & (Constant) & 1.662 & .084 & & 19.842 & .000 \\
\hline & What political party dose your mother prefer? & .369 & .028 & .400 & 13.078 & .000 \\
\hline 2 & $\begin{array}{l}\text { (Constant) } \\
\text { What political party dose your mother prefer? } \\
\text { What political party dose your mother prefer? }\end{array}$ & $\begin{array}{l}1.334 \\
.190 \\
.342\end{array}$ & $\begin{array}{l}.087 \\
.033 \\
.036\end{array}$ & $\begin{array}{l}.206 \\
.337\end{array}$ & $\begin{array}{c}15.291 \\
5.783 \\
9.437\end{array}$ & $\begin{array}{l}.000 \\
.000 \\
.000\end{array}$ \\
\hline
\end{tabular}

What political party is you associated with?

Table 2: Regression coefficient for youth party affiliation associated with their parent's party affiliation.

\begin{tabular}{|c|c|c|c|c|c|c|}
\hline Parents vs. Friends & Mean & Std. deviation & $\mathbf{T}$ & Df & Sig. (2-tailed) & eta squared statistic \\
\hline Influenced by Parents & 2.40 & 1.548 & \multirow[t]{2}{*}{3.067} & \multirow[t]{2}{*}{900} & \multirow[t]{2}{*}{.003} & \multirow[t]{2}{*}{0.001} \\
\hline Influenced by Friends & 1.92 & 1.253 & & & & \\
\hline
\end{tabular}

Table 3: Paired-samples t-test parents vs. friends.

Parents vs. Siblings
Influenced by Parents
Influenced by Siblings

Influenced by Siblings

\begin{tabular}{|c|c|c|c|c|c|}
\hline Mean & Std. Deviation & T & Df & Sig. (2-tailed) & eta squared statistic \\
\hline 2.40 & 1.548 & 1.642 & 900 & .107 & 0.04 \\
\hline 2.06 & 1.322 & & & & \\
\hline
\end{tabular}

Table 4: Paired-samples t-test parents vs. siblings.

association between youth party affiliation and their parent's political party affiliation.

\section{Hypothesis 2: Parents are a more significant as compare to peer/other in interpersonal source}

Paired-samples t-tests was used to measure parents are a more important as compare to peer/other in interpersonal source: The paired-samples t-tests was used when you measure the same person in terms of his/her response to two different questions (e.g., asking him/ her to rate the importance in terms of life satisfaction on two dimensions of life: health, financial security). In this case, both dimensions should be rated on the same scale (e.g., from $1=$ not at all influence to=very influential).

Table paired-samples t-tests was used to measure parents are a more important as compare to peer/other in interpersonal source (Table 3).

A paired-samples t-test was conducted to evaluate what extent your decision of who to vote for was influenced by the interpersonal communication through the parents sites as compare to interpersonal communication through the friends. There was a statistically significant decrease in Friends scores from $\mathrm{M}=1.92, \mathrm{SD}=1.253$ ) to Social Media $[\mathrm{M}=2.40, \mathrm{SD}=1.54, \mathrm{t}(900)=3.067, \mathrm{p}<.003]$. The eta squared statistic (0.001) indicated a Limited influence (Table 4).

A paired-samples t-test was conducted to evaluate what extent your decision of who to vote for was influenced by the interpersonal communication through the Parents Sites as compare to interpersonal communication through the Siblings. There was a statistically significant decrease in siblings scores from Parents, $\mathrm{M}=2.06, \mathrm{SD}=1.322$ ) to Parents $[\mathrm{M}=2.40, \mathrm{SD}=1.54, \mathrm{t}(900)=.107, \mathrm{p}<0.21]$. The eta squared statistic (0.04) indicated a Limited influence (Table 5).

A paired-samples t-test was conducted to evaluate what extent your decision of who to vote for was influenced by the interpersonal communication through the Parents Sites as compare to interpersonal communication through the Teachers. There was a statistically significant decrease in teachers scores from Parents, $M=1.74, S D=1.129)$ to Parents $[\mathrm{M}=2.40, \mathrm{SD}=1.54, \mathrm{t}(900)=3.249, \mathrm{p}<.002]$. The eta squared statistic (0.16) indicated a Moderate influence (Table 6).

A paired-samples t-test was conducted to evaluate what extent your decision of who to vote for was influenced by the interpersonal communication through the Parents Sites as compare to interpersonal communication through the significant others. There was a statistically significant decrease in significant others scores from Parents, $M=1.96$, $\mathrm{SD}=1.24)$ to Parents $[\mathrm{M}=2.40, \mathrm{SD}=1.54, \mathrm{t}(900)=2.16, \mathrm{p}<0.35]$. The eta squared statistic (0.08) indicated a Limited influence (Table 7).

A paired-samples t-test was conducted to evaluate what extent your decision of who to vote for was influenced by the interpersonal communication through the Parents Sites as compare to interpersonal communication through the religious leaders. There was a statistically significant decrease in religious leaders scores from Parents, $M=2.08$, $\mathrm{SD}=1.504$ to Parents $[\mathrm{M}=2.40, \mathrm{SD}=1.54, \mathrm{t}(900)=1.23, \mathrm{p}<0.222]$. The eta squared statistic (0.02) indicated a Limited influence (Table 8).

A paired-samples t-test was conducted to evaluate what extent your decision of who to vote for was influenced by the interpersonal communication through the Parents Sites as compare to interpersonal communication through the Celebrity. There was a statistically significant decrease in Celebrity scores from Parents, $M=2.09$, $\mathrm{SD}=1.362)$ to Parents $[\mathrm{M}=2.40, \mathrm{SD}=1.54, \mathrm{t}(900)=1.31, \mathrm{p}<0.194]$. The eta squared statistic (0.03) indicated a Limited influence.

In the light of above all tabulated data research found that parents is highly influential among all interpersonal source of communication. All source have limited influence expect teacher which having moderate influence against parents according to respondents reported data. These finding showed same results as prior researchers (Table 9).

Above data reflect interesting fact that respondent more frequently discuss political matters with their friend, while family, parent and sibling stood at second position with slightly above the social media, but when talk about influence statistic showed that parent are more influential.

Means of different interpersonal sources showed parents kept more influence on youth's voting behaviour, followed by celebrity, religious leader and siblings. While friend teacher and significant other enlist in least important in changing voting behaviors.

H3 Media exposure (newspaper, television, radio and internet) are more positively associated than interpersonal communication in voting behaviour of youth

To find out which pattern of communication is more influential 
Citation: Waseem Iqbal Y, Shabir G (2017) The Influence of Interpersonal Communication, Traditional Media, and New Media Sources on Youth's Voting Behavior; A Study of Pakistan General Election 2013 Campaign. J Mass Communicat Journalism. 7: 343. doi: 10.4172/21657912.1000343

Page 8 of 11

\begin{tabular}{|c|c|c|c|c|c|c|}
\hline Parents vs. Teachers & Mean & Std. Deviation & $\mathbf{T}$ & Df & Sig. (2-tailed) & eta squared statistic \\
\hline Influenced by Parents & 2.40 & 1.548 & \multirow[t]{2}{*}{3.249} & \multirow[t]{2}{*}{900} & \multirow[t]{2}{*}{.002} & \multirow[t]{2}{*}{0.16} \\
\hline Influenced by teachers & 1.74 & 1.129 & & & & \\
\hline
\end{tabular}

Table 5: paired-samples t-test parents vs. teachers.

\begin{tabular}{|c|c|c|c|c|c|c|c|c|c|c|c|}
\hline Parents Vs. Significant Other & Mean & Std. Deviation & T & Df & Sig. (2-tailed) & eta squared statistic \\
\hline Influenced by Parents & 2.40 & 1.548 & 2.162 & 900 & .035 \\
\hline Influenced by Significant Other & 1.96 & 1.240 & & \\
\end{tabular}

Table 6: Paired-samples t-test parents vs. significant other.

\begin{tabular}{|c|c|c|c|c|c|c|}
\hline Parents Vs Religious Leader & Mean & Std. Deviation & $\mathbf{T}$ & Df & Sig. (2-tailed) & eta squared statistic \\
\hline Influenced by Parents & 2.40 & 1.548 & \multirow[t]{2}{*}{1.236} & \multirow[t]{2}{*}{900} & \multirow[t]{2}{*}{.222} & \multirow[t]{2}{*}{0.02} \\
\hline Influenced by Religious Leaders & 2.08 & 1.504 & & & & \\
\hline
\end{tabular}

Table 7: Paired-samples t-test parents vs. religious leader.

\begin{tabular}{|c|c|c|c|c|c|c|c|c|c|c|c|}
\hline Parents Vs Celebrity & Mean & Std. Deviation & T & Df & Sig. (2-tailed) & eta squared statistic \\
\hline Influenced by Parents & 2.40 & 1.548 & 1.315 & 900 & .194 \\
\hline Influenced by Celebrity & 2.09 & 1.362 & & & &
\end{tabular}

Table 8: Paired-samples t-test parents vs. celebrity.

\begin{tabular}{|c|c|c|c|c|c|c|c|c|c|}
\hline & 0 Days & 1 Day & 2 Days & 3 Days & 4 Days & 5 Days & 6 Days & 7 Days & M \\
\hline Family & 23.1 & 13.2 & 17.0 & 7.5 & 7.5 & 5.7 & 3.4 & 22.6 & 3.87 \\
\hline Friend & 12.2 & 19.9 & 11.2 & 4.8 & 4.3 & 6.2 & 4.8 & 36.6 & 4.42 \\
\hline Significant Others & 39.1 & 5.7 & 18.9 & 7.5 & 5.7 & 1.9 & 7.5 & 13.2 & 3.36 \\
\hline Social Media & 50.9 & 9.4 & 5.7 & 7.5 & 0.00 & 3.8 & 1.9 & 20.8 & 3.85 \\
\hline
\end{tabular}

Table 9: Frequency of political discussion with their interpersonal communication sources.

than other, research simply took their influential frequency along with their means (Table 10).

Above tabulated data distantly showed that parents are more influential as compare to any interpersonal or media orientated communication, followed by television and social networking sites. So researcher conclude that both interpersonal communication as well as other media exposure matter a lot while shaping there voting behaviour, but parents, television and social media enlist at the top.

\section{Analysis and Discussion}

This study reflects a number of interesting facts into the voting behavior and attitudes of young voters in 2013 general election of Pakistan. First hypothesis revealed high consistency with prior studies that Youth party's affiliations are likely more positive due to parents' party affiliation. Researcher found that young voters believe that they have similar political beliefs as their parents. There is another fact that respondents reported that they are more frequently do their political discussion with friends, but in casting vote the role of parents is most influential as compared to any other interpersonal communication source. This may reflect that university students (many of whom live away from home) are spend more time with their friends and discuss their political beliefs. But contemporary research findings are similarly with previous studies that indicate parents are the prime source of influence on younger voters. Achen, 2002; Alexander, 1978; Austin and Pinkleton, 2001; Atkin, 1981; Beak, 1977; Bengtson, 1986; Chaffee, Jackson-Beck, Dhrall and Wilson, 1977; Connel 1971),: Cowart, 2003; Connell, 1972; Easton and Dennis, 1969; Greenstein Fridkin and Kenney, 2007; Hess and Torney, 1967; Hyman, 1959; Langton and Jenning, 1969; Jennings and Niemi, 1968); Jennings and Niemi , 1974; McDevitt and Kiousis, 2007; McDevitt and Chaffee, 2002; Sapiro 2004; Tolley, 1973 and Torney-Purta, 1995.

The findings of all afore mentioned researcher matched with the current research. Above cited researches indicate that parental mediation paly important role in shaping political orientation of their children.

Due to explosion of information technology (IT) drastically change our whole society. IT radically effected our all sector of society, our defence system, means of transportation, health system, education system, business orientation and our patterns of communication. With the blessing of information communication technology gave us opportunity not only improve our communication patterns but also help us to get latest information regarding any issue. Here in Pakistani culture children are mostly under the influence of their parents regarding any decision, the reason behind is the outlook of our society. Like other decisions children are under the influence of their parents for their voting decision, but with the passage of time and intensity of media strikes our culture and youth's sources of information changed and gave little bit independence to youth in their decision. Despite of this radical change in our society outlook, still parents have highly influential role in youth's decision.

According to Gallup Pakistan that in this age of information Pakistani youth involved all other interpersonal means of communication, and they more likely to talk with their friends, and television is their primary source of information with $40 \%$ and internet lies on second position with more than $30 \%$ in which social media stood top with $19 \%$, but when talk about voting behaviour change, parents still on top with $23 \%$. This fact aroused because parents mediate their youth's behaviours from their childhood. Here researcher also found other means of communication and media sources viable to young adults they are not politically associated. Researcher draw another conclusion that election campaign only effective or vulnerable youth voters, which are not clear in there party affiliation or undecided voters. Above all researches ratify researcher findings and showed that this phenomena of youth party affiliation is more likely associated with parent's party affiliation. This fact is not only prevail here in Pakistan 
Citation: Waseem Iqbal Y, Shabir G (2017) The Influence of Interpersonal Communication, Traditional Media, and New Media Sources on Youth's Voting Behavior; A Study of Pakistan General Election 2013 Campaign. J Mass Communicat Journalism. 7: 343. doi: 10.4172/21657912.1000343

Page 9 of 11

\begin{tabular}{|c|c|c|c|c|c|c|}
\hline & Not at all Influential & Slightly Influential & Somewhat Influential & Very Influential & Extremely Influential & Mean \\
\hline Parents & $43.4 \%$ & $18.9 \%$ & $9.4 \%$ & $11.3 \%$ & $17 \%$ & 2.40 \\
\hline Friends & $52.8 \%$ & $22.6 \%$ & $11.3 \%$ & $5.7 \%$ & $7.5 \%$ & 1.92 \\
\hline Siblings & $49.1 \%$ & $22.6 \%$ & $9.4 \%$ & $11.3 \%$ & $7.5 \%$ & 2.06 \\
\hline Teachers & $58.5 \%$ & $24.5 \%$ & $7.5 \%$ & $3.8 \%$ & $5.7 \%$ & 1.74 \\
\hline Significant Other & $52.8 \%$ & $17 \%$ & $17 \%$ & $7.5 \%$ & $5.7 \%$ & 1.96 \\
\hline Religious Leaders & $58.5 \%$ & $11.3 \%$ & $7.5 \%$ & $9.4 \%$ & $13.2 \%$ & 1.08 \\
\hline Celebrity & $45.3 \%$ & $30.2 \%$ & $5.7 \%$ & $7.5 \%$ & $11.3 \%$ & 2.09 \\
\hline Television & $30.2 \%$ & $30.2 \%$ & $28.3 \%$ & $3.8 \%$ & $7.5 \%$ & 2.38 \\
\hline Radio & $52.8 \%$ & $26.4 \%$ & $11.3 \%$ & $1.9 \%$ & $7.5 \%$ & 1.85 \\
\hline Newspaper & $30.2 \%$ & $37.7 \%$ & $7.5 \%$ & $11.3 \%$ & $13.3 \%$ & 2.03 \\
\hline Internet News & $37.7 \%$ & $28.3 \%$ & $22.6 \%$ & $5.7 \%$ & $5.7 \%$ & 1.83 \\
\hline Blogs & $54.7 \%$ & $20.8 \%$ & $17 \%$ & $1.9 \%$ & $5.7 \%$ & 1.90 \\
\hline Social Networking Sites & $32.1 \%$ & $26.4 \%$ & $17 \%$ & $9.4 \%$ & $15.10 \%$ & 2.29 \\
\hline Political Parties Web & $39.6 \%$ & $34 \%$ & $7.5 \%$ & $5.7 \%$ & $13.2 \%$ & 2.01 \\
\hline
\end{tabular}

Table 10: Frequency table of different source influence on voting behavior.

but also in developed or more politically mature societies e.g., USA and Europe. Gallup International also asked teens to compare their political belief with those of their parents. $21 \%$ teen of US say they are more liberal than their parents $7 \%$ reported they are more conservative than their parents, and $71 \%$ say their political belief is about the same as their parents.

Second hypothesis "Parents are a more important as compare to peer/other in interpersonal source" was tested by Paired-samples t-tests. In the light of all tabulated data research found that parents is highly influential among all interpersonal source of communication. All source have limited influence expect teacher which having moderate influence against parents according to respondents reported data. These finding showed same results as prior researchers. The interpersonal communication sources of youth except parents are like siblings, friends, teacher, religious leaders and significant others, but they have not heavy influential like parents. Definitely there sources keep some influence in political socialization of youth, and respondents reported that they involved with these interpersonal sources or conduct political discussion with them but they have less impressed of influenced through these source, even in this research found that majority of youth mostly conduct political discussion with their friend. Interpersonal communication sources influence on political learning and it is important and might possibly constitute the one factor in voting behaviour that is more to change and modification than other influences such a traditional media or new media. This research is doubly important inasmuch as it will further suggest a causal link between siblings, friend, teachers, religious leaders and significant others, but parents are more influential than any other interpersonal influence. Like above quoted studies, current research showed same result that parents are more influential as compare to any other source, here researcher indicate that friends are on if we see table of frequency of political discussion with their interpersonal communication sources.

Pervious researchers also indicate political orientation or socialization paly important role in developing political behaviour. Political socialization is the process in which youth acquire political understanding, attitude and behaviour (cowart and Powell). Current study results resemble with prior research, because youth political behaviour is learned as mention Hyman in 1959.

According to prior finding Peers also have influence on their friend, teenagers attempt to "adequate in" and experience peer pressure to conform, they have heavily influence in decision making regarding many social activities, but they have not played major role in the formation of voting behaviours as reflected in the study of Campbell 1980; and Powell and cowert,2003 study. Researcher has concluded that peer influence is also matter a lot in the education of political socialization but still they are least important in bolting vote. Here in Pakistan this phenomena rate high due to Pakistani conservative cultural outlook, because in Pakistani cultural youth value their parents in major social political and economic issues even they are well educated or kept international exposure. This phenomena not only based on due to family cultural outlook but also due to the religious belief. Apart from family, parents, siblings here is sense of social identity like Baradari system also kept force on youth to vote such party which belong to their parents or their Baradari. In the support of current study McDevitt and Kiousis 2006; Youniss, 1998, also reflect that friends, peers other means of interpersonal communication expect parents do not heavily influence in political behaviour change but may have important role in their political discussion. in the support of current study research provided evidence from Jennings and Niemi 1968, study that political belief were transmitted from parents to children's, like party affiliation and political behaviour and Connell 1972 argued that youth voting political orientation or political, voting behaviour is the by-product of their parents party affiliation.

Here is an interesting finding that parents are still significant predictor of their political behaviour but their intensity is decreased in current study which is supported by Sapiro 2004 study, that family may not predominant influence it was once considered, she noted that exploring the processes, stages, and development of political socialization and practices in ever changing process. It is because increase access to internet and other traditional media has an impact on youth's political identity formation. Due to this prevailing situation the parents has taken a back seat in the age of information in coming election but still on the top list of interpersonal element.

Frequency of political discussion with their interpersonal communication sources reflect that respondents frequently talk with friend regarding politic with 4.42 mean, while family and social media stood second with 3.87 and 3.85 means respectively. On the other hand when researcher talk about difference in means of interpersonal sources for changing in youth's voting behaviours depicted that parents are most significantly predictor of voting behaviour of youth as compare to any other source of interpersonal communication. According to the result of above result researcher concluded their discussions with that family have substantial power in influencing political behaviour of youth. This power not only play important role in political orientation but also in changing the voting behaviour in their desire party. 
Citation: Waseem Iqbal Y, Shabir G (2017) The Influence of Interpersonal Communication, Traditional Media, and New Media Sources on Youth's Voting Behavior; A Study of Pakistan General Election 2013 Campaign. J Mass Communicat Journalism. 7: 343. doi: 10.4172/21657912.1000343

Page 10 of 11

In their Third hypothesis "Media exposure (newspaper, television, radio and internet) are more positively associated than interpersonal communication in voting behaviour of youth" researcher found that parents are most significant predictor of their voting choice followed by traditional media television and social media from new media form. Despite many political, economic and social developments, Pakistan remains a male dominant and family oriented society in many respects. Pakistan like many Asian countries has strong tradition of interpersonal communication, social gatherings, Baradri system, campaign rallies; corner meetings play a significant role in political socialization of Pakistani youth. In elections day's people of whole county actively participate corner meetings which were held main Centre of community (which is common setting place for any community) and exchange news and discuss social, economic, local issues and political issues. This phenomenon just like a bourgeois public sphere. Such interpersonal interactions not only groom political orientation but also play significant role in changing voting behaviours. Almost all literature cited studies supported current research that interpersonal communication kept their influence on changing voting behaviour of youth while comparison current study statistic reflect that both interpersonal and media outlet have significant influence of youth voting choice but parents, television and social media are most significant predictor of their voting choice, because interpersonal especially parents mobilized, political educated significantly, but it did not have direct effect on voting behaviour through mass media. In other words, both interpersonal communication and mass media had a direct and indirect influence on voting behaviour of youth. Youth is most vulnerable part of society through media because they are inexperienced, they have not political affiliate with any party yet, so media have heave influence on them as compare to any other segment of society. When research talk about media influence, he argued that although some cited literature suggested newspapers effects on voting behaviours, but result in this study shown that television and social media news, discussion on social media had significant effect on voting behaviour. These contrary findings may be due to difference in demographic of current study. Current study based on youth only which ages between 18 to 30 , who are educated economically sound to some extent and university student, used latest means of communication, interact with people on social media. So their primary source are also different from pervious suggest researchers. This study result suggested that traditional media or new media exposure did not predict voting behaviours. However, parental mediation and political socialization predict media campaign exposure. People with strong political parties' affiliations paid more attentions and heavily active on social media to changes voting behaviours of their peers groups during election campaign. These finding further confirm the theory of uses and gratification. Respondents' apparently evaluate the ability of media to satisfy political needs. So due youth heave involvement on social media and television, they first got political information from television and then discuss on social media and finally convinced other peers. Researcher concluded these argument by saying that interpersonal communication especially parents effects seemed to be more powerful than mass communication on voting behaviour. At the aggregate level, researcher found that interpersonal communication had more consistently positive effects than media use on voting behaviours. As much researcher suggested parents still significant predictor of youth political orientation, belief and voting behaviour followed by television and social media. The reason of parent's domination in making political view is that, they have first-hand making political orientation by mediated communication. From childhood children used to watch media talked under the supervision of their parents, while television is still primary source of information is this modern age, but social media got high importance due their interactive and interpersonal communication natures feature.

\section{Conclusion}

This study was based on self-reported survey to shed some light on the Influence of Interpersonal Communication, Traditional Media, and New Media Sources on Youth's Voting Behavior. This study found that interpersonal communication and media exposure has a different level of influence on youth's voting behavior during election days. Interpersonal communication dose increase youth's political socialization and facilitate to develop party affiliation. Data of this study showed that there is significant association between respondent party and their parent party, and it seemed slightly variation between their political beliefs. Youth's political view tilt moderate to liberal while their parent moderate to conservative, due to majority of respondent reported their political views alike to their parents, so researcher can say that still parents are primary influential factor in shaping political view of youth in the modern era. And this assumption validate by current study by showing that in 2013 election respondents and their parents mostly voted to same party. Other interpersonal sources kept certain influence with limitation, but parents have an edge their mending youth's views from childhood. Parents influence factor rate high not only in interpersonal means of communication but also in media source as well.

In second half of study researcher focused what extend media exposure influencing voting behavior of youth. Here research found an interesting fact that, no doubt media enjoyed their esteem develop position in society, and it has radically changed our every sector of society, but still having little involvement in shaping social, political view of society. This is fact media provide topic for discussion, raise issue, give opportunity to innovative ideas, but their acceptance chance still depends on people interpersonal consensus. So researcher safely says that media have more influential or more vulnerable to undecided voter or youth, who still not affiliate to any party. This argument was proved in 2013 election that media establish PTI as popular party or youth's party, but result of election told different story. Current study also reflects that most of the youth voted PLMN as their parent's do. However there is no one who can denied media exposure in shaping voting behavior. But effectiveness of medium vary due to availability, specific features and people preference.so researcher found that television is prime source of information as well as significant in shaping political behaviors of youth. But due to rapid growth of internet, now social media succeeding television, and in a very short time we can see social media is prime source of information as well as powerful influential factor due to interactive interpersonal communication features. This study revealed indirect effects or influence of media exposure on youth. Media content provide topic for discussion and social media furnished a virtual space to youth for discussion on these political topics to ripen consensus on said issue. Most of the studies presumes youth is passive in receiving election content from campaign. However, respondents could intentionally ignore the message (except undecided voters or youth) and not let the content any impact on their decision. This study also showed that there is slightly difference in developing political behaviors of youth on the base of demographic variation like (gender, age, education and income level). There is possibility in source preference due to variation in demographic of youth, but this is fact that television is major source of information followed by social media for youth, and they are mostly used to discuss political matters with their friend, but youth's party 
Citation: Waseem Iqbal Y, Shabir G (2017) The Influence of Interpersonal Communication, Traditional Media, and New Media Sources on Youth's Voting Behavior; A Study of Pakistan General Election 2013 Campaign. J Mass Communicat Journalism. 7: 343. doi: 10.4172/21657912.1000343

Page 11 of 11

affiliation significantly associated with their parents 'party affiliation. Interpersonal communication sources especially parents seems to be more powerful than media exposure either traditional media or new media in influencing voting behavior of youth. This study advocate that political parties, their candidates, media organizations and especially election campaign organizers should number of time while developing election campaign, this study suggests such media campaign and political content has only indirectly influence on youth voting behavior of youth. In other word media content develop mediated interpersonal communication or increase like hood of youth to discuss political content with other interpersonal sources, which such communication they might be influenced. Because interpersonal and media exposure jointly play their part in influencing voting behavior of youth, so we cannot under estimate any source, but highlight fact to develop better election campaign for forthcoming elections.

\section{References}

1. Lau RR, Redlawsk DP (2006) How voters decide: Information processing during election campaigns. New York: Cambridge UP.

2. Jackson DJ (2002) Entertainment and politics: The influence of pop culture on young adult political socialization. New York: Peter Lang Publishing, Inc.

3. Hyman H (1959) Political socialization: A study in the psychology of political behavior. American Journal of Sociology 65: 521

4. LeVine R (1963) Political socialization and culture change. In: Clifford Geerts editor. Old societies and new states. New York: Free Press.

5. Atkin CK (1981) Communication and political socialization. In: Nimmo DD, Sanders KR editors. Handbook of political communication. Beverly Hills, CA: Sage, pp: 299-328.

6. Connell RW (1972) Political socialization in the American family: The evidence reexamined. Public Opinion Quarterly 36: 323-333.

7. Jennings MK, Niemi RG (1968) The transmission of political values from parent to child. American Political Science Review 62: 169-184.

8. Powell L, Cowart J (2003) Political campaign communication: Inside and out Boston: Allyn and Bacon.

9. Quarles RC (1979) Mass media use and voting behavior: The accuracy of political perceptions among first-time and experienced voters. Communication Research 6: 407-436.

10. Campbell A, Converse PE, Miller WE, Stokes DE (1960) The American voter New York: John Wiley \& Sons, Inc

11. Fournier P, Nadeau R, Blais A, Gidengil E, Nevitte N (2004) Time-of-voting decision and susceptibility to campaign effects. Electoral Studies 23: 661-681.

12. Torney Purta J (1995) Psychological theory as a basis for political socialization research: Individuals' Construction of Knowledge. Perspectives on Political Science 23-33.

13. Easton D, Dennis J (1969) Children in the political system. New York: McGrawHill 388-178-179.

14. Greenstein FI (1965) Children and politics. New Haven: Yale University Press.

15. Kiousis S, McDevitt M, Wu X (2005) The genesis of civic qwareness: Agenda setting in political socialization. Journal of Communication 55: 756-774.

16. Hyman HH (1959) Political socialization: Study in the psychology of political behavior. Psychology Free Press

17. Niemi RG, Ross RD, Alexander J (1978) The similarity of political values of parents and college-age youths. Public Opinion Quarterly 42: 503-520.

18. Glass J, Bengtson VL (1986) Attitude similarity in three-generation families: Socialization, status inheritance, or reciprocal influence? American Sociological Review 51: 685-698.

19. McDevitt M, Chaffee S (2002) From top-down to trickle-up influence: Revisiting assumptions about the family in political socialization. Political Communication 19: $281-301$.

20. Campbell BA (1980) A theoretical approach to peer influence in adolescent socialization. American Journal of Political Science 24: 324-345.
21. McDevitt M, Kiousis S (2006) Deliberative learning: An evaluative approach to interactive civic education. Communication Education 55: 247-264.

22. Yates M, Youniss J (1998) Community service and political identity development in adolescence. Journal of Social Issues 54: 495-512.

23. Sapiro V (2004) Not your parents' political socialization: Introduction for a new generation. Annual Review of Political Science 7: 1-23.

24. Willis J (2007) The Media Effect: How the News Influences Politics and Government. California, US: Praeger Press.

25. Klapper JT (1960) The Effects of Mass Communication. Free Press.

26. Neumann N (1984) Spiral of silence: Public opinion, our social skin. Chicago, US: University of Chicago Press.

27. Miller WL (1991) Media and voters. Oxford, UK: Clarendon Press.

28. Rogers E (2002) Inter media processes and powerful media effects. In: Bryant $\mathrm{J}$, Zillman D editors. Media Effects; Advances in Theory and Research. London, UK: Routledge.

29. Islam R (2008) Information and Public Choice: From Media Markets to Policy Making. Washington, DC: World Bank Publications.

30. Burton G (2010) Media and Society: Critical Perspectives. Maidenhead, UK Open University Press

31. Yaser N, Mahsud N, Chaudhry IA (2011) Effects of Exposure to Electronic Media Political Content on Voters" Voting Behavior. Berkeley Journal of Socia Sciences.

32. Shawar D, Asim M (2012) Voting Behavior of People towards Different Political Parties in District Faisalabad, Pakistan.

33. Tolbert CJ, McNeal RS (2003) Unraveling the effects of the Internet on political participation? Political Research Quarterly 56: 175-185.

34. Mutz DC (1997) Mechanisms of momentum: Does thinking make it so? Journal of Politics 59: 104-125.

35. Trent JS, Friedenberg RV (2008) Political campaign communication. New York Rowman and Littlefield.

36. Hollihan TA (2009) Uncivil wars: Political campaigns in a media age. New York: Bedford/St. Martin's.

37. Jamieson KH (1996) Packaging the presidency: A history and criticism of political advertising. New York: Oxford UP.

38. Putnam RD (1995) Tuning in, tuning out: The strange disappearance of social capital in America. PS: Political Science \& Politics 28: 664-683.

39. Henn M, Weinstein M, Wring D (2002) A generation apart? Youth and political participation in Britain. British Journal of Politics and International Relations 4 167-192.

40. De Vreese $\mathrm{CH}$ (2007) Digital renaissance: Young consumer or citizen? The ANNALS of the American Academy of Political and Social Science

41. Dahlgren $P$ (2000) The Internet and the democratization of civic culture. Political Communication 17: $335-340$

42. Gamson WA (1992) Talking politics. Unlocking potential with the best learning and research solutions, Academic

43. Sotirovic M, McLeod JM (2001) Values, communication behavior, and political participation. Political Communication 18: $273-300$

44. Rainie L, Horrigan B (2007) Election 2006 online: The number of Americans citing the Internet as the source of most of their political news and information doubled since the last mid-term election. Pew Internet and American Life Project

45. Smith A, Rainie L (2008) The Internet and the 2008 Election. Pew Internet and American Life Project

46. Calenda D, Mosca L (2007) Youth online: Researching the political use of the Internet in the Italian context. Department of Political and Social Sciences

47. Dahlgren P, Olsson T (2007) Young activists, political horizons and the Internet: Adapting the net to one's purposes. In Young citizens in the digital age: Political engagement, young people, and new media 68-81.

48. Vergeer M, Hermans L (2008) Analysing online political discussions: Methodological considerations. Javnost - The Public 15: 37-56. 